\title{
Pengumuman Perhitungan Baru Indeks LQ45 dan IDX30: Apakah Ada Reaksi pada Pasar Modal Indonesia?
}

\author{
Rizal A Bimantara ${ }^{1}$, Ely Siswanto ${ }^{2}$, Yuli Soesetio ${ }^{3}$ \\ 1, 2, 3 Universitas Negeri Malang \\ ${ }^{1}$ rizalagusb@gmail.com, ely.siswanto.fe@um.ac.id, 3yuli.soesetio.fe@um.ac.id \\ *Penulis korespondensi
}

\begin{abstract}
This study discusses whether there an influence from the announcement of the new calculation of LQ45 and IDX30 index. This study uses indicators of abnormal return, cumulative abnormal return, and trading volume activity as a measure of market reaction. The population of this study is the companies incorporated in the IDX30 index. The sampling method uses purposive sampling method and obtained sample of 20 companies. The window period in this study is 11 days. Statistical tests using paired sample t-test and Wilcoxon sign rank test. The results of this study indicate there are no differences in the average abnormal return and trading volume activity before and after the event. There are differences in cumulative abnormal returns before and after events. This shows that investors have anticipated the news and the market has adjusted to a new balance before the announcement of the new LQ45 and IDX30 index calculations officially applied.
\end{abstract}

Keywords: lq45; idx30; abnormal return; cumulative abnormal return; trading volume activity; event study

\begin{abstract}
Abstrak
Studi ini membahas mengenai apakah terdapat pengaruh dari adanya peristiwa pengumuman perhitungan baru indeks LQ45 dan IDX30. Penelitian ini menggunakan indikator return tidak normal, kumulatif return tidak normal, dan volume perdagangan saham sebagai pengukur reaksi pasar. Populasi penelitian ini adalah perusahaan yang tergabung dalam indeks IDX30. Metode pengambilan sampel menggunakan Teknik purposive sampling dan diperoleh sampel 20 perusahaan. Periode jendela pada penelitian ini yaitu 11 hari. Uji statistik menggunakan paired sample t-test dan wilcoxon sign rank test. Hasil penelitian ini menunjukkan tidak terdapat perbedaan rata-rata return tidak normal dan volume perdagangan saham sebelum dan sesudah peristiwa. Terdapat perbedaan kumulatif return tidak normal sebelum dan sesudah peristiwa. Hal ini menunjukkan bahwa investor sudah mengantisipasi berita serta pasar sudah melakukan penyesuaian menuju keseimbangan baru sebelum pengumuman perhitungan baru indeks LQ45 dan IDX30 resmi diterapkan.
\end{abstract}

Kata kunci: lq45; idx30; return tidak normal; kumulatif return tidak normal; volume perdagangan saham 


\section{PENDAHULUAN}

Pasar modal merupakan salah satu faktor kunci kesuksesan dalam pembangunan ekonomi suatu negara. Pasar modal dibangun dengan maksud menggerakkan perekonomian suatu negara melalui kekuatan swasta dan mengurangi beban negara (Samsul, 2015:58). Dalam sudut pandang negara, pasar modal memiliki peran penting sebagai sarana pengumpulan dana dalam pembangunan perekonomian selain meminjam dana dari pihak asing.

Pasar modal adalah tempat dimana berbagai pihak khususnya perusahaan menjual saham (stock) dan obligasi (bond) dengan tujuan dari hasil penjualan tersebut nantinya akan dipergunakan sebagai tambahan dana atau untuk memperkuat modal perusahaan (Fahmi, 2012:55). Pasar modal berfungsi sebagai lembaga perantara, karena pasar modal dapat menghubungkan pihak yang membutuhkan dana dengan pihak yang mempunyai kelebihan dana. Disamping itu, pasar modal dapat mendorong terciptanya alokasi dana yang efisien, karena dengan adanya pasar modal maka pihak yang kelebihan dana (investor) dapat memilih alternatif investasi yang memberikan return yang paling optimal (Tandelilin, 2010:26).

Pasar modal merupakan suatu instrumen ekonomi yang menarik untuk di teliti. Hal ini dicerminkan pada waktu adanya sebuah peristiwa terduga atau tidak terduga mengakibatkan para investor bereaksi. Pada sewaktu terjadinya sebuah peristiwa, maka peristiwa tersebut memiliki kandungan informasi. Para investor akan menangkap sinyal-sinyal kandungan informasi dari peristiwa tersebut. Kandungan informasi dapat berupa berita baik (good news) atau berita buruk (bad news) (Tandelilin, 2010:565). Oleh karena itu, bagi investor informasi mempunyai peran penting dalam pengambilan keputusan untuk berinvestasi di pasar modal.

Terkait cara pengambilan keputusan investor dalam berinvestasi di pasar modal, dapat menunjukkan bentuk efisiensi pasar modal. Fama (1970, dalam Hartono, 2012:25) menyajikan tiga macam bentuk utama dari efisiensi pasar berdasarkan ketiga macam bentuk dari informasi yaitu efisiensi pasar bentuk lemah, bentuk setengah kuat, dan bentuk kuat. Hartono (2012:25) mengatakan bahwa bentuk efisiensi pasar dapat ditinjau dari segi ketersediaan informasinya dan dapat juga dilihat dari kecanggihan pelaku pasar dalam pengambilan keputusan berdasarkan analisis dari informasi yang tersedia. Selain itu, adapun event study dapat juga digunakan untuk menguji kandungan informasi dan efisiensi pasar khususnya efisiensi pasar bentuk setengah kuat.

Pasar dikatakan efisien bentuk setengah kuat jika pasar dapat bereaksi dengan cepat untuk menyerap abnormal return untuk menuju ke harga keseimbangan yang baru (Hartono, 2012:92). Selain itu, pada pasar efisien bentuk setengah kuat, return tak normal hanya terjadi di seputar pengumuman (publikasi) suatu peristiwa sebagai representasi dari respon pasar terhadap pengumuman tersebut (Tandelilin, 2010:223). Dengan demikian pengujian efisiensi pasar bentuk setengah kuat dilakukan setelah pengujian kandungan informasi serta informasi tersebut direspon cepat oleh pasar.

Bursa Efek Indonesia mengadakan sosialisasi perdana Pada tanggal 08 November 2018 di ruang seminar gedung Bursa Efek Indonesia terkait rencana penerapan free float pada penghitungan indeks LQ45 dan IDX30. Secara harfiah ke dalam Bahasa Indonesia, free float memiliki arti mengambang bebas. Menurut Bursa Efek Indonesia, free float adalah total saham 
scripless yang dimiliki oleh investor dengan kepemilikan kurang dari 5\%. Oleh karena itu, dapat disimpulkan bahwa free float atau mengambang bebas karena saham adalah saham yang benar-benar dapat diperdagangkan oleh investor secara bebas di pasar saham dan saham free float ini tidak termasuk saham yang dimiliki oleh pemegang saham pengendali.

Hasil dari ruang seminar Bursa Efek Indonesia (BEI) pada 8 November 2018 menyatakan bahwa tujuan penerapan free float pada perhitungan indeks LQ45 dan IDX 30 sebagai berikut. Pertama bertujuan memberikan gambaran riil nilai saham yang dapat diperoleh investor dengan mengecualikan nilai saham yag dimiliki oleh pemegang saham pengendali atau strategis. akan melakukan penyesuaian metode perhitungan indeks yang sudah ada saat ini. Penyesuaian dilakukan dengan menambahkan indikator rasio free float terhadap kapitalisasi pasar. Kedua, meningkatkan efisiensi pasar portofolio dengan berkurangnya bobot saham-saham dengan free float rendah. Ketiga, Mendorong perusahaan tercatat saham untuk menambah porsi saham free float. Keempat, telah menjadi common practice perhitungan indeks oleh index providers dan bursa-bursa utama di dunia. (Idx.co.id, 8 November 2018).

Dampak dari sosialisasi perdana Bursa Efek Indonesia terkait rencana penerapan free float pada penghitungan indeks LQ45 dan IDX30 mengakibatkan IHSG mengalami kemerosotan. Sejak tiga hari yang lalu, dunia saham diberi kabar yang menggemparkan dari Bursa Efek Indonesia. Indeks Harga Saham Gabungan (IHSG) merosot sebesar 1,72 persen menjadi 5.874,15. Hal ini dipengaruhi oleh salah satu metode baru yang diumumkan dan diterapkan oleh BEI mengenai penghitungan indeks dengan memperhitungkan rasio free float atau minimal jumlah saham emiten yang beredar terhadap kapitalisasi pasar. (Utami, 12 November 2018). Selain itu, dampak dari rencana penerapan metode ini memiliki pengaruh besar terhadap beberapa saham, terutama pada saham yang tergabung dalam indeks LQ45 dan IDX30.

Selain itu, dampak dari rencana penerapan metode ini memiliki pengaruh besar terhadap beberapa saham, terutama pada saham yang tergabung dalam indeks LQ45 dan IDX30. Rencana Bursa Efek Indonesia mengubah perhitungan bobot indeks LQ45 dan IDX30 menjadi pemicu pelemahan saham PT HM Sampoerna Tbk (HMSP) dan PT Unilever Indonesia Tbk (UNVR). Harga saham HMSP tercatat anjlok 10,26\% menjadi Rp 3.410/ saham dengan nilai transaksi Rp 729,11 miliar. Sementara saham UNVR merosot 5,79\% ke Rp 40.250/saham dengan nilai transaksi Rp 453,91 miliar. Menurut riset Panin Sekuritas yang dipublikasikan siang ini, wacana perubahan perhitungan bobot kedua indeks tersebut, berdasarkan besaran free float menjadi pemicu para pengelola dana mulai melakukan melepas saham yang memiliki free float kecil. Berdasarkan data BEI, free float HMSP saat ini hanya 7,5\%. Demikian pula dengan UNVR yang hanya memiliki free float $15 \%$ dan saham PT Gudang Garam Tbk (GGRM) dengan free floar 24,45\%. Bobot saham-saham ini akan berkurang setelah BEI menerapkan aturan baru dalam menghitung bobot penghuni indeks LQ45 dan IDX30. Sementara itu, saham-saham seperti PT Bank Mandiri Tbk (BMRI) dengan free float 40\%, PT Bank Central Asiat Tbk (BBCA) dengan free float 43,51\%, PT Bank Rakyat Indonesia Tbk (BBRI) dengan free float 43,25\%, PT Astra International Tbk (ASII) dengan free float 49,89\% dan PT Indofood Sukses Makmur Tbk (INDF) dengan free float 49,93\%, akan memiliki bobot yang lebih besar nantinya. Pasalnya bobot kedua saham tersebut akan berkurang setelah bursa mengubah basis perhitungan menjadi rasio free float 
terhadap kapitalisasi pasar. Dimana saham-saham dengan saham free float yang besar akan memiliki bobot yang lebih besar terhadap indeks LQ45 dan IDX30. (Cnbcindonesia.com, 9 November 2018).

Pada tanggal 23 November 2018, Bursa Efek Indonesia semakin serius terhadap perencanaan penerapan free float pada penghitungan indeks LQ45 dan IDX30. Hal ini terlihat pada tanggal tersebut keluar surat edaran No: Peng-00893/BEI.OPP/11-2018 yang berjudul pengumuman perubahan metodologi indeks LQ45 dan IDX30. Surat edaran tersebut berisi tentang Bursa Efek Indonesia telah melakukan evaluasi dan akan melakukan perubahan metodologi indeks LQ45 dan IDX30. Bursa Efek Indonesia senantiasa melakukan pengembangan pasar untuk mewujudkan kegiatan pasar modal yang teratur, wajar, dan efisien dengan salah satu upaya melakukan penyempurnaan metodologi indeks LQ45 dan IDX30. (Pengumuman BEI No: Peng-00893/BEI.OPP/11-2018, 23 November 2018).

Berdasarkan paparan data yang ada terkait dengan rencana peresmian metode free float adjusted index pada perhitungan indeks LQ45 dan IDX30 oleh Bursa Efek Indonesia (BEI). Maka dari itu, peneliti tertarik terkait dengan pengumuman peresmian metode free float adjusted index pada perhitungan indeks LQ45 dan IDX30 pada 23 November 2018 apakah berdampak pada pasar modal di Indonesia. Untuk membuktikan apakah peristiwa pengumuman peresmian metode free float adjusted index pada perhitungan indeks LQ45 dan IDX30 memberikan dampak lebih terhadap kondisi pasar modal indonesia maka akan dilakukan pengujian kandungan informasi peristiwa tersebut dengan menggunakan event study. Menurut Samsul (2015:229), event study diartikan mempelajari pengaruh suatu peristiwa terhadap harga saham di pasar pada saat peristiwa terjadi dan beberapa saat setelah peristiwa terjadi. Tolak ukur yang digunakan dalam penelitian ini adalah abnormal return, cumulative abnormal return, dan trading volume activity.

Tujuan penelitian ini adalah untuk menguji apakah terdapat perbedaan abnormal return, cumulative abnormal return, dan trading volume activity sebelum dan sesudah pengumuman perhitungaan baru indeks LQ45 dan IDX30. Dengan demikian, diharapkan dapat digunakan sebagai tambahan informasi dan pengetahuan bagi calon investor untuk mengambil keputusan berinvestasi. Bagi emiten, dapat dijadikan bahan pertimbangan dalam menentukan kebijakankebijakan perusahaan. Dari pembahasan ini diajukan hipotesis sebagai berikut:

$\mathrm{H}_{1}=$ Terdapat perbedaan abnormal return yang signifikan sebelum dan sesudah pengumuman perhitungan baru Indeks LQ45 dan IDX30.

$\mathrm{H}_{2}=$ Terdapat perbedaan cumulative abnormal return yang signifikan sebelum dan sesudah pengumuman perhitungan baru Indeks LQ45 dan IDX30.

$\mathrm{H}_{3}=$ Terdapat perbedaan trading volume activity yang signifikan sebelum dan sesudah pengumuman perhitungan baru Indeks LQ45 dan IDX30.

\section{METODE}

Penelitian ini termasuk dalam jenis penelitian komparatif. Penelitian ini menggunakan pendekatan kuantitatif. Penelitian ini termasuk dalam penelitian event study dan menggunakan market-adjusted model dalam menguji kandungan informasi terhadap peristiwa yang terjadi. 
Variabel yang digunakan dalam penelitian ini adalah abnormal return, cumulative abnormal return, dan trading volume activity. Periode jendela (event window) dilakukan selama 11 hari yaitu 5 hari sebelum peresmian dan 5 hari sesudah peresmian, dimana pemilihan hari tersebut bukan secara berurutan melainkan hari aktif saat perdagangan saham di bursa terjadi.

Penelitian ini menggunakan metode purposive sampling dan memperoleh sampel sebanyak 20 emiten. Keseluruhan perushaan tersebut terhimpun dalam indeks IDX30 dan tidak melakukan corporate actions selama event window.

Terdapat beberapa langkah yang harus dilakukan terlebih dahulu, dan untuk menguji perbedaan abnormal return, cumulative abnormal return, dan trading volume activity sebelum dan sesudah peristiwa pengumuman perhitungan baru indeks LQ45 dan IDX30 dilakukan dengan menggunakan uji beda. Adapun tahapan-tahapan yang dilakukan dalam perhitungan data adalah sebagai berikut:

Menghitung actual return saham harian, untuk mengetahui perbandingan antara harga saham hari ini dengan harga saham sebelumnya dengan rumus.

$$
R_{i, t}=\frac{P_{i, t}-P_{i, t-1}}{P_{i, t-1}}
$$

Menghitung expected return saham harian, yang menggunakan market adjusted model untuk mengetahui tingkat return yang diharapkan yaitu dengan rumus.

$$
E[R]_{i, t}=\frac{I H S G_{t}-I H S G_{t-1}}{I H S G_{t-1}}
$$

Menghitung abnormal return untuk masing-masing saham emiten untuk periode 5 hari sebelum dan 5 hari sesudah pengumuman.

$$
\mathrm{AR}_{\mathrm{i}, \mathrm{t}}=\mathrm{R}_{\mathrm{i}, \mathrm{t}}-\mathrm{E}\left[\mathrm{R}_{\mathrm{i}, \mathrm{t}}\right]
$$

Menghitung cumulative abnormal return untuk masing-masing saham emiten untuk periode 5 hari sebelum dan 5 hari sesudah pengumuman.

$$
\mathrm{CAR}_{\mathrm{i}, \mathrm{t}}=\sum_{\mathrm{a}=\mathrm{t} 3}^{\mathrm{t}} A R_{i, a}
$$

Menghitung trading volume activity untuk masing-masing saham emiten untuk periode 5 hari sebelum dan 5 hari sesudah pengumuman.

$$
\operatorname{TVA}_{i, t}=\frac{\text { Volume Perdagangan }_{i, t}}{\text { Saham Beredar }}
$$

Setelah diperoleh hasil dari perhitungan diatas, selanjutnya akan dilakukan menggunakan uji normalitas menggunakan uji kolmogorov smirnov. Tahap akhir dari rangkaian pengujian adalah uji paired sample t-test untuk data yang berdistribusi normal dan wilcoxon sign rank test untuk data yang berdistribusi tidak normal. Uji tersebut bertujuan untuk memastikan adanya perbedaan signifikansi abnormal return, cumulative abnormal return, dan trading volume activity antara sebelum dan sesudah peristiwa pengumuman perhitungan baru indeks LQ45 dan IDX30. Pengujian dalam penelitian ini menggunakan SPSS 25. 


\section{HASIL DAN PEMBAHASAN}

Berdasarkan tabel 1, variabel abnormal return dan cumulative abnormal return menghasilkan nilai signifikansi (asymp. sig 2-tailed) > 0,05. Artinya data tersebut berdistribusi normal sehingga uji beda yang sesuai dan dapat digunakan adalah uji paired sample t-test. Akan tetapi, trading volume activity menghasilkan nilai signifikansi $<0,05$ maka data tersebut berdistribusi tidak normal sehingga uji yang digunakan wilcoxon sign rank test.

Tabel 1. Hasil Pengujian Kolmogorov Smirnov

\begin{tabular}{lcccccc}
\hline \multirow{2}{*}{ Periode } & \multicolumn{2}{c}{ AR } & \multicolumn{2}{c}{ CAR } & \multicolumn{2}{c}{ TVA } \\
& Sebelum & Sesudah & Sebelum & Sesudah & Sebelum & Sesudah \\
\hline Kolmogorov smirnov & 0,179 & 0,224 & 0,229 & 0,322 & 0,231 & 0,396 \\
Asymp Sig.(2-tailed) & 0,200 & 0,200 & 0,200 & 0,098 & 0,200 & 0,010 \\
\hline
\end{tabular}

Sumber: Data diolah peneliti menggunakan SPSS 25 (2019)

Berdasarkan tabel 2, abnormal return tertinggi periode sebelum peristiwa terjadi pada $\mathrm{t}_{-1}$ sebesar 0,008240. Abnormal return terendah periode sebelum peristiwa terjadi pada $\mathrm{t}_{-2}$ sebesar $-0,005018$. Selain itu, abnormal return tertinggi periode sesudah peristiwa terjadi pada $\mathrm{t}_{+4}$ sebesar 0,007789. Abnormal return terendah periode sesudah peristiwa pada $\mathrm{t}_{+2}$ sebesar -0,005618. Rata-rata abnormal return seluruh saham IDX30 periode sebelum peristiwa adalah sebesar 0,002388 dan rata-rata abnormal return sesudah peristiwa sebesar $-0,000419$. Hal ini menunjukkan bahwa event pengumuman perhitungaan baru indeks LQ45 dan IDX30 memberikan pengaruh yang negatif terhadap psikologi investor. Serta hasil abnormal return negatif sesudah peristiwa terbentuk sejak $t_{+1}$ sampai $t_{+3}$ menandakan bahwa event pengumuman perhitungaan baru indeks LQ45 dan IDX30 merupakan informasi bad news bagi investor.

Tabel 2. Abnormal Return Saham IDX30

\begin{tabular}{cccc}
\hline Periode & AR & Periode & AR \\
\hline $\mathrm{t}_{-5}$ & 0,004920 & $\mathrm{t}_{+1}$ & $-0,003085$ \\
$\mathrm{t}_{-4}$ & 0,002931 & $\mathrm{t}_{+2}$ & $-0,005618$ \\
$\mathrm{t}_{-3}$ & 0,000868 & $\mathrm{t}_{+3}$ & $-0,001732$ \\
$\mathrm{t}_{-2}$ & $-0,005018$ & $\mathrm{t}_{+4}$ & 0,007789 \\
$\mathrm{t}_{-1}$ & 0,008240 & $\mathrm{t}_{+5}$ & 0,000553 \\
$\mathrm{t}_{-0}$ & $-0,000641$ & & \\
\hline
\end{tabular}

Sumber: Data diolah peneliti menggunakan SPSS 25 (2019)

Pada periode sesudah peristiwa, investor banyak yang melakukan penjualan saham sehingga harga saham turun dan return yang didapatkanpun lebih kecil dari return ekspektasi. Pada periode sesudah peristiwa biasanya banyak investor yang memanfaatkan situasi seperti ini untuk mendapatkan harga saham yang belum terlalu tinggi demi memperoleh keuntungan yang lebih besar saat kondisi pasar sudah membaik. Akan tetapi, berdasarkan hasil uji 
hipotesis menunjukkan bahwa tidak terdapat perbedaan yang signifikan antara abnormal return sebelum dan sesudah peristiwa pengumuman perhitungan baru indeks LQ45 dan IDX30 pada saham perusahaan yang tercatat di indeks IDX30.

Tabel 3. Hasil Uji paired sample t-test Abnormal Return Periode Penelitian

\begin{tabular}{|c|c|c|c|c|}
\hline \multirow{2}{*}{ Periode } & \multicolumn{2}{|c|}{ Mean } & \multirow{2}{*}{$\begin{array}{c}\text { Sig. } \\
\text { (2 tailed) }\end{array}$} & \multirow{2}{*}{ Keterangan } \\
\hline & Sebelum & Sesudah & & \\
\hline $\mathrm{t}_{-1}$ dan $\mathrm{t}_{+1}$ & ,008240 &,- 003085 & 1,976 & ,063 \\
\hline$t_{-2}$ dan $t_{+2}$ &,- 005018 &,- 005617 & ,083 & ,934 \\
\hline $\mathrm{t}_{-3}$ dan $\mathrm{t}_{+3}$ & ,000868 & ,000868 & ,316 & ,755 \\
\hline $\mathrm{t}_{-4}$ dan $\mathrm{t}_{+4}$ & ,002931 & ,007789 &,- 814 & ,426 \\
\hline $\mathrm{t}_{-5}$ dan $\mathrm{t}_{+5}$ & ,004920 & ,000553 &, 576 & ,572 \\
\hline
\end{tabular}

Sumber Data diolah peneliti menggunakan SPSS 25 (2019)

Hasil uji paired sample t-test dapat dilihat pada tabel 3 yang menunjukkan nilai signifikansi sebelum dan sesudah peristiwa pada $t_{-1}$ dan $t_{+1}$ sampai $t_{-5}$ dan $t_{+5}$ menunjukkan hasil signifikansi yang lebih besar dari nilai signifikansi 0,05 atau 5\%. Oleh karena itu, hipotesis 1 yang diajukan peneliti ditolak atau $\mathrm{H}_{0}$ diterima.

Tidak terdapat perbedaan abnormal return yang signifikan sebelum dan sesudah peristiwa pengumuman perhitungan baru indeks LQ45 dan IDX30 diduga dikarenakan informasi dari pengumumuan tersebut tidak mampu membuat pergerakan saham diatas pergerakan normal yang menyebabkan perubahan return yang terjadi tidak cukup besar. Hal ini menunjukkan bahwa pelaku pasar tidak terlalu terpengaruh dengan adanya pengumuman tersebut. Indikasi lain penyebab tidak terdapat perbedaan abnormal return sebelum dan sesudah peristiwa yaitu mengingat pendapat yang dikemukakan oleh Hartono (2012) menyatakan bahwa pasar modal di Indonesia masih tergolong pasar modal yang transaksinya tipis (thin market). Artinya bahwa volume perdagangan pada pasar modal di Indonesia masih tergolong kecil, sehingga dalam melihat reaksi pasar terhadap suatu peristiwa melalui return tidak terdeteksi atau tidak mencerminkan secara jelas terdapat perbedaan. Hal tersebut dibuktikan oleh penelitian yang dilakukan oleh Satya (2013), menghasilkan bahwa tidak terdapat perbedaan pada harga saham antara sebelum dan sesudah publikasi laporan keuangan interim perusahaan yang disebabkan oleh saham Indonesia masih bersifat lemah dan dangkal (thin market).

Selain itu, pasar tidak bereaksi terhadap pengumuman diduga dikarenakan investor dan pasar sudah melakukan penyesuaian sebelum metode perhitungan free float adjusted index resmi diterapkan dan diumumkan ke publik. Penyesuaian tersebut dapat dilihat pada informasi yang disajikan oleh berita.baca.co.id yaitu "Meskipun baru sosialisasi, rencana penerapan indeks untuk LQ45 dan IDX30 ternyata sudah memakan korban, seiring dengan informasi yang mulai meluas di kalangan sekuritas, nasabah, dan juga wartawan. Investor di pasar buru-buru menyesuaikan portofolionya, salah satunya dengan membuang sahamsaham yang porsinya akan lebih kisut di indeks. Beberapa saham tersebut adalah PT HM Sampoerna Tbk (HMSP) yang tenggelam 10,29\%, PT Unilever Indonesia Tbk (UNVR) 
yang tumbang 4,67\%, dan PT Gudang Garam (GGRM) yang melemah 3,13\% hanya dalam satu hari perdagangan 9 November 2018". Selain itu, berita dari indopremier.com juga menyatakan sebagai berikut "Direktur BEI, Hasan Fawzi menjelaskan, BEI akan menambahkan kriteria pembobotan berupa free float ke dalam Indeks LQ45 dan IDX30, namun tetap mengedepankan penilaian terkait kapitalisasi pasar, likuiditas dan catatan catatan fundamental emiten. "Setelah itu, kami akan memasukkan kriteria free float," ucapnya. Lebih lanjut dia menyebutkan, ketentuan terkait indeks LQ45 yang mamasukkan kriteria free float akan diberlakukan untuk periode Februari-Juli 2019. "Kami akan mempercepat pengumuman perhitungan indeks tersebut (LQ45 dan IDX30). Mungkin pertengahan Januari 2019," ujar Hasan. Hasan menyatakan, upaya BEI mempercepat pengumuman perhitungan indeks LQ45 dan IDX30 untuk memberikan ruang bagi pengelola investasi dalam mengantisipasi kondisi pasar. "Kondisi yang terjadi saat ini (pelemahan indeks) hanya bersifat jangka pendek untuk menuju keseimbangan baru," tuturnya". Informasi tersebut menunjukkan bahwa investor dan pasar sudah melakukan penyesuaian serta menuju keseimbangan baru yang menyebabkan abnormal return tidak signifikan.

Penelitian event study yang dilakukan oleh peneliti sudah pernah dilakukan oleh peneliti terdahulu, yaitu dengan mengangkat berbagai macam peristiwa sebagai event penelitian. Temuan hasil penelitian ini sesuai dengan penelitian yang dilakukan oleh Rahmadhani dan Darmawan (2018) yang meneliti tentang perbedaan abnormal return sebelum dan sesudah peristiwa pengumuman investment grade Indonesia yang menunjukkan hasil bahwa tidak terdapat perbedaan abnormal return yang signifikan sebelum dan sesudah peristiwa. Penelitian yang dilakukan oleh Uswa, dkk (2016) tentang perbedaan abnormal return sebelum dan sesudah eksekusi kasus narkoba juga menunjukkan hasil bahwa tidak terdapat perbedaan abnormal return yang signifikan pada sebelum dan sesudah peristiwa.

Tabel 4. Cumulative Abnormal Return Saham IDX30

\begin{tabular}{cccc}
\hline Periode & CAR & Periode & CAR \\
\hline t-1 s/d t-2 & 0,00322 & $\mathrm{t}+1 \mathrm{~s} / \mathrm{d} \mathrm{t}+2$ & $-0,00870$ \\
$\mathrm{t}-1 \mathrm{~s} / \mathrm{d} \mathrm{t}-3$ & 0,00409 & $\mathrm{t}+1 \mathrm{~s} / \mathrm{d} \mathrm{t}+3$ & $-0,01043$ \\
$\mathrm{t}-1$ s s $\mathrm{d}$ t-5 & 0,01194 & $\mathrm{t}+1 \mathrm{~s} / \mathrm{d} \mathrm{t}+5$ & $-0,00209$ \\
\hline
\end{tabular}

Sumber: Data diolah peneliti menggunakan SPSS 25 (2019)

Berdasarkan tabel 4 mendapatkan hasil bahwa cumulative abnormal return periode sebelum peristiwa menghasilkan nilai positif dan sesudah peristiwa menghasilkan nilai negatif. Cumulative abnormal return periode sebelum pada $t_{-1} \mathrm{~s} / \mathrm{d}_{-2}$ menghasilkan nilai 0,00322 , $\mathrm{t}_{-1} \mathrm{~s} / \mathrm{d} \mathrm{t}_{-3}$ menghasilkan nilai 0,00409, dan $\mathrm{t}_{-1} \mathrm{~s} / \mathrm{d}_{-5}$ menghasilkan nilai 0,01194. Selain itu, cumulative abnormal return periode sesudah peristiwa pada $t_{+1} s / \mathrm{d} \mathrm{t}_{+2}$ menghasilkan nilai $-0,00870, t_{+1} s / d t_{+3}$ menghasilkan nilai $-0,01043$, dan $t_{+1} s / d t_{+5}$ menghasilkan nilai $-0,00209$. Hal ini dapat dianalisis bahwa selama periode pengamatan, investor mendapat penurunan cumulative abnormal return. 
Tabel 5. Hasil Uji paired sample t-test Cumulative Abnormal Return Periode Penelitian

\begin{tabular}{|c|c|c|c|c|c|}
\hline \multirow[b]{2}{*}{ Periode } & \multicolumn{2}{|c|}{ Mean } & \multirow[b]{2}{*}{$\mathbf{t}$} & \multirow[b]{2}{*}{ Sig (t-tailed) } & \multirow[b]{2}{*}{ Keterangan } \\
\hline & Sebelum & Sesudah & & & \\
\hline $\mathrm{t}_{-1}$ to $\mathrm{t}_{-2} \mathrm{Vs} \mathrm{t}_{+1}$ to $\mathrm{t}_{+2}$ & ,001600 &,- 005900 & 1,974 & ,299 & $\mathrm{H}_{0}$ diterima \\
\hline $\mathrm{t}_{-1}$ to $\mathrm{t}_{-3} \mathrm{Vst}_{+1}$ to $\mathrm{t}_{+3}$ & ,002433 &,- 007400 & 3,070 & ,092 & $\mathrm{H}_{0}$ diterima \\
\hline$t_{-1}$ to $t_{-5} V s t_{+1}$ to $t_{+5}$ & ,005240 &,- 005380 & 5,453 & ,005 & $\mathrm{H}_{0}$ ditolak \\
\hline
\end{tabular}

Sumber: Data diolah peneliti menggunakan SPSS 25 (2019)

Dalam perhitungan abnormal return sebelumnya diketahui bahwa nilai uji paired sample t-test abnormal return menghasilkan tidak terdapat perbedaan signifikan abnormal return sebelum dan sesudah peristiwa. Hasil uji hipotesis cumulative abnormal return yang ditunjukkan pada tabel 5 dalam pengujian pada $t_{-1} V s t_{-2}$ dan $t_{+1} V s t_{+2}$, serta $t_{-1} V s t_{-3}$ dan $\mathrm{t}_{+1} \mathrm{Vs}_{+3}$ menghasilkan nilai signifikansi lebih dari 0,05 atau $5 \%$ sehingga $\mathrm{H}_{0}$ diterima atau tidak terdapat perbedaan yang signifikan. Namun, hasil uji paired sample t-test pada $\mathrm{t}_{-1}$ to $t_{-5} V s t_{+1}$ to $t_{+5}$ cumulative abnormal return menghasilkan nilai signifikansi kurang dari 0,05 , sehingga hipotesis 2 yang diajukan peneliti diterima atau $\mathrm{H}_{0}$ ditolak, artinya terdapat perbedaan yang signifikan cumulative abnormal return sebelum dan sesudah pengumuman perhitungan baru indeks LQ45 dan IDX30.

Terdapat perbedaan cumulative abnormal return sebelum dan sesudah peristiwa pengumuman perhitungan baru indeks LQ45 dan IDX30 pada penelitian ini diduga disebabkan oleh kemungkinan adanya kebocoran informasi sebelum peristiwa diumumkan ke publik. Kemungkinan adanya kebocoran informasi terdapat pada hasil seminar yang diadakan Bursa Efek Indonesia pada tanggal 08 November 2018 tentang sosialisasi perencanaan penerapan free float pada penghitungan indeks LQ45 dan IDX30. Informasi lain terdapat pada indopremier. com pada tanggal 12 November 2018 yang menyebutkan bahwa "Direktur BEI, Hasan Fawzi, menyebutkan "Kami akan mempercepat pengumuman perhitungan indeks tersebut (LQ45 dan IDX30). Mungkin pertengahan Januari 2019," ujar Hasan. Hasan menyatakan, upaya BEI mempercepat pengumuman perhitungan indeks LQ45 dan IDX30 untuk memberikan ruang bagi pengelola investasi dalam mengantisipasi kondisi pasar". Selain itu, informasi yang terdapat pada finansialku.com pada tanggal 12 November 2018 menyebutkan bahwa "Saham-saham dalam indeks LQ45 dan IDX30 akan kembali dilakukan penghitungan ulang berdasarkan jumlah saham beredarnya dan sisi likuiditas, serta fundamental perusahaannya. Penerapan metode baru perhitungan indeks LQ45 dan IDX30 pun akan direalisasikan pada bulan Februari 2019. Kabarnya, penerapan metode baru ini akan memiliki 4 tahap dalam penerapannya, yaitu pertama, sosialisasi dan diskusi dengan pelaku pasar yang diadakan pada minggu ke-1 hingga 2 November 2018. Kedua, pengumuman resmi bursa terkait rencana penerapan free float pada saham indeks LQ45 dan IDX30 yang diadakan pada minggu ke-3 November 2018. Ketiga, pengumuman perubahan konstituen dan bobot saham indeks LQ45 dan IDX30 yang akan diadakan pada minggu ke-3 Januari 2019. Keempat, penerapan free float yang efektif pada efektif saham indeks dan IDX30 yang akan diadakan pada 1 Februari 2019". Melalui informasi tersebut dengan hasil penelitian ini, menunjukkan bahwa terdapat kebocoran informasi kepada investor, sehingga investor sudah mengantisipasi berita dan 
sudah melakukan penyesuaian di pasar yang dapat dilihat pada hasil abnormal return yang tidak signifikan dalam penelitian ini.

Indikasi lain terdapat perbedaan yang signifikan cumulative abnormal return sebelum dan sesudah peristiwa pengumuman perhitungan baru indeks LQ45 dan IDX30, diduga disebabkan oleh faktor lain yaitu informasi yang terdapat pada cnbcindonesia.com pada tanggal 30 November 2018 "Indeks Harga Saham Gabungan (IHSG) mengakhiri pekan ini dengan catatan buruk. Dibuka melemah 0,04\%, IHSG mengakhiri hari dengan memperlebar kekalahannya menjadi $0,84 \%$ ke level 6.056,13" dan "IHSG kembali menjauh dari level psikologis 6.100 akibat aksi jual investor asing pada saham-saham berkapitalisasi besar. Aksi jual investor asing dipengaruhi sentimen sektoral dan perubahan yang terjadi dalam komposisi MSCI All Country World Index (ACWI) yang berlaku efektif pada 30 November 2018. Manajer Investasi mulai mengatur ulang komposisi portofolio dengan mengacu MSCI ACWI sebagai acuan dengan memasukkan saham PT Bukit Asam Tbk (PTBA) dan PT Pabrik Kertas Tjiwi Kimia (TKIM)".

Penelitian event study yang dilakukan oleh peneliti sudah pernah dilakukan oleh peneliti terdahulu, yaitu dengan mengangkat berbagai macam peristiwa sebagai event penelitian. Temuan hasil penelitian ini sesuai dengan penelitian yang dilakukan oleh Septiani dan Akbar (2014) yang meneliti tentang sebelum dan sesudah peristiwa merger dan akuisisi yang menunjukkan hasil bahwa terdapat cumulative abnormal return yang signifikan. Penelitian yang dilakukan oleh Fauzi, dkk (2017) yang meneliti tentang reaksi return saham pada peristiwa pengumuman obligasi syariah juga menunjukkan hasil bahwa terdapat perbedaan cumulative abnormal return yang signifikan sebelum dan sesudah peristiwa.

Tabel 6. Trading Volume Activity Saham IDX30

\begin{tabular}{cccc}
\hline Periode & TVA & Periode & TVA \\
\hline $\mathbf{t}_{-5}$ & 0,001558 & $\mathbf{t}_{+1}$ & 0,001408 \\
$\mathbf{t}_{-4}$ & 0,001769 & $\mathbf{t}_{+2}$ & 0,001531 \\
$\mathbf{t}_{-3}$ & 0,001336 & $\mathbf{t}_{+3}$ & 0,001633 \\
$\mathbf{t}_{-2}$ & 0,001979 & $\mathbf{t}_{+4}$ & 0,002133 \\
$\mathbf{t}_{-1}$ & 0,001791 & $\mathbf{t}_{+5}$ & 0,006753 \\
$\mathbf{t}_{-0}$ & 0,001210 & & \\
\hline
\end{tabular}

Sumber: Data diolah peneliti menggunakan SPSS 25 (2019)

Berdasarkan tabel 6 dapat diketahui bahwa trading volume activity tertinggi periode sebelum peristiwa terjadi pada $t_{-2}$ sebesar 0,001979 . Trading volume activity terendah periode sebelum peristiwa terjadi pada $t_{-3}$ sebesar 0,001336. Selain itu, trading volume activity tertinggi periode sesudah peristiwa terjadi pada $t_{+5}$ sebesar 0,006753. Trading volume activity terendah periode sesudah peristiwa pada $t_{+1}$ sebesar 0,001408 . Rata-rata trading volume activity seluruh saham IDX30 periode sebelum peristiwa adalah sebesar 0,001687 dan rata-rata trading volume activity sesudah peristiwa sebesar 0,002692. Hal ini menunjukkan bahwa perubahan trading volume activity tidak cukup besar sebelum dan sesudah peristiwa. 
Tabel 7. Hasil Uji Hipotesis Trading Volume Activity Periode Penelitian

\begin{tabular}{|c|c|c|c|c|c|}
\hline \multirow{2}{*}{ Periode } & \multicolumn{2}{|c|}{ Mean } & \multirow{2}{*}{ Z } & \multirow{2}{*}{$\begin{array}{c}\text { Sig } \\
\text { (t-tailed) }\end{array}$} & \multirow{2}{*}{ Keterangan } \\
\hline & Sebelum & Sesudah & & & \\
\hline $\mathrm{t}-1$ dan $\mathrm{t}+1$ & ,001791 & ,001408 & $-2,016$ &, 044 & $\mathrm{H}_{0}$ ditolak \\
\hline $\mathrm{t}-2$ dan $\mathrm{t}+2$ & ,001979 & ,001531 & $-1,979$ & ,048 & $\mathrm{H}_{0}$ ditolak \\
\hline $\mathrm{t}-3$ dan $\mathrm{t}+3$ & ,001336 & ,001633 & $-1,829$ &, 067 & $\mathrm{H}_{0}$ diterima \\
\hline $\mathrm{t}-4$ dan $\mathrm{t}+4$ & ,001769 & ,002133 & $-1,307$ & ,191 & $\mathrm{H}_{0}$ diterima \\
\hline $\mathrm{t}-5$ dan $\mathrm{t}+5$ & ,001557 & ,006753 & $-3,360$ & ,001 & $\mathrm{H}_{0}$ ditolak \\
\hline $\mathrm{t}-1 \mathrm{~s} / \mathrm{d} \mathrm{t}-5$ dan $\mathrm{t}+1 \mathrm{~s} / \mathrm{d} \mathrm{t}+5$ & 0,001687 & 0,002692 &,- 135 & ,893 & $\mathrm{H}_{0}$ diterima \\
\hline
\end{tabular}

Sumber: Data diolah peneliti menggunakan SPSS 25 (2019)

Berdasarkan tabel 7, dapat dilihat bahwa hasil uji wilcoxon sign rank test pada $\mathrm{t}_{-1}$ dan $t_{+1}, t_{-2}$ dan $t_{+2}$, serta $t_{-5}$ dan $t_{+5}$ menghasilkan nilai signifikansi kurang dari 0,05 atau 5\%, sehingga dapat dikatakan terdapat perbedaan yang signifikan. Akan tetapi, jika melihat hasil keseluruhan sebelum dan sesudah menghasilkan nilai signifikansi 0,893 maka hipotesis 3 peneliti ditolak atau $\mathrm{H}_{0}$ diterima atau dapat ditarik kesimpulan bahwa tidak terdapat perbedaan yang signifikan trading volume activity sebelum dan sesudah peristiwa pengumuman perhitungan baru indeks LQ45 dan IDX30.

Indikasi terdapat perbedaan yang signifikan pada $t_{-1}$ dan $t_{+1}$ serta $t_{-2}$ dan $t_{+2}$ adalah mengingat bahwa pasar modal di Indonesia merupakan pasar modal yang sedang berkembang termasuk dalam thin market. Hartono (2012) menyatakan bahwa pasar modal di Indonesia masih tergolong pasar modal yang transaksinya tipis (thin market). Artinya bahwa volume perdagangan pada pasar modal di Indonesia masih tergolong kecil, sehingga dalam melihat reaksi pasar terhadap suatu peristiwa melalui return tidak terdeteksi atau tidak mencerminkan secara jelas terdapat perbedaan. Oleh karena itu, melihat reaksi pasar terhadap suatu peristiwa lebih baik melalui perhitungan trading volume activity. Hal tersebut dibuktikan oleh penelitian yang dilakukan oleh Satya (2013), menghasilkan bahwa tidak terdapat perbedaan harga saham sebelum dan sesudah publikasi laporan keuangan interim perusahaan. Akan tetapi, terdapat perbedaan pada volume perdagangan saham sebelum dan sesudah publikasi laporan keuangan interim perusahaan. Selain itu, dapat dibuktikan bahwa terdapat perbedaan yang signifikan trading volume activity pada $t_{-1}$ dan $t_{+1}$ serta $t_{-2}$ dan $t_{+2}$ dalam penelitian ini.

Indikasi lain terdapat perbedaan yang signifikan pada $t_{-1}$ dan $t_{+1}$ serta $t_{-2}$ dan $t_{+2}$ diduga investor menangkap sinyal dari pengumuman perhitungan baru indeks LQ45 dan IDX30, hal ini dikarenakan perhitungan baru indeks LQ45 dan IDX30 dengan metode free float adjusted index mengakibatkan manajer investasi (MI) bereaksi dengan melakukan rebalancing. Indeks LQ45 dan IDX30 merupakan indeks acuan dari reksadana indeks dan exchange traded fund yang sering digunakan oleh manajer investasi. Oleh karena itu, dampak dari perhitungan baru pada indeks LQ45 dan IDX30 mempengaruhi perilaku manajer investasi untuk menyesuaikan portofolionya dengan mengikuti acuan baru. Sehingga, manajer investasi melepas atau menjual saham perusahaan yang bobotnya turun akibat perhitungan baru indek LQ45 dan IDX30 serta memilih atau membeli saham perusahaan yang bobotnya naik. Informasi tersebut terdapat pada alinea.id menyebutkan bahwa "Manajemen BEI mengatakan, penerapan penghitungan 
free float ini bertujuan untuk meningkatkan fairness perdagangan saham-saham emiten di pasar modal. Selama ini, pergerakan indeks di dorong oleh pergerakan saham-saham dengan kapitalisasi pasar besar saja. Analis Senior CSA Research Institute, Reza Priyambada mengatakan, pelaku pasar melakukan penyesuaian (adjustment) sebagai dampak penerapan sistem ini. Penyesuaian terutama dilakukan manajer investasi yang memiliki produk reksadana, dengan indeks acuannya LQ45 maupun IDX30". Hal ini dapat dilihat pada gambar 4.3, bahwa pergerakan trading volume activity $t_{-2}$ sampai dengan $t_{0}$ mengalami penurunan dan $t_{0}$ sampai dengan $t_{+2}$ mengalami peningkatan. Oleh karena itu dapat dikatakan informasi yang ada pada peristiwa pengumuman perhitungan baru indeks LQ45 dan IDX30 direaksi cepat oleh investor tercermin dari trading volume activity yang signifikan pada $t_{-1}$ dan $t_{+1}$ serta $t_{-2}$ dan $t_{+2}$.

Selain itu, terdapat perbedaan yang signifikan pada $t_{-5}$ dan $t_{+5}$ diduga disebabkan oleh faktor lain, informasi tersebut terdapat pada cnbcindonesia.com "Indeks Harga Saham Gabungan (IHSG) mengakhiri pekan ini dengan catatan buruk. Dibuka melemah 0,04\%, IHSG mengakhiri hari dengan memperlebar kekalahannya menjadi 0,84\% ke level 6.056,13. Perdagangan berlangsung luar biasa ramai dengan nilai transaksi mencapai Rp 16,8 triliun. Volume perdagangan adalah 14,07 miliar unit saham dan frekuensi perdagangan adalah 447.274 kali" dan "IHSG kembali menjauh dari level psikologis 6.100 akibat aksi jual investor asing pada saham-saham berkapitalisasi besar. Aksi jual investor asing dipengaruhi sentimen sektoral dan perubahan yang terjadi dalam komposisi MSCI All Country World Index (ACWI) yang berlaku efektif pada 30 November 2018. Manajer Investasi mulai mengatur ulang komposisi portofolio dengan mengacu MSCI ACWI sebagai acuan dengan memasukkan saham PT Bukit Asam Tbk (PTBA) dan PT Pabrik Kertas Tjiwi Kimia (TKIM)”.

Selain itu, hasil pengujian keseluruhan tidak terdapat perbedaan yang signifikan trading volume activity sebelum dan sesudah peristiwa pengumuman perhitungan baru indeks LQ45 dan IDX30 pada penelitian ini dapat disebabkan oleh perilaku investor. Pada periode penelitian, peristiwa pengumuman perhitungan baru indeks LQ45 dan IDX30 memiliki kandungan informasi. Akan tetapi, tidak cukup kuat untuk membuat investor benar-benar merubah aktivitas perdagangan sahamnya. Pergerakan trading volume activity pada hari peristiwa atau $t_{0}$ sampai dengan $t_{+4}$ bergerak naik sedikit demi sedikit. Akan tetapi, pada $t_{+5}$ trading volume activity mengalami kenaikan secara drastis dan pada $t_{+5}$ merupakan respon investor paling besar pada periode penelitian ini.

Hal ini berarti psikologis investor tidak menentu, dapat disimpulkan bahwa pada periode penelitian investor mengambil keputusan yang berbeda-beda. Informasi yang terdapat pada cnbcindonesia.com menyebutkan bahwa "Meskipun mengawali perdagangan dengan menguat 0,27\%, IHSG harus mengakhiri awal pekan dengan melemah 0,12\% ke level 6.005 . Reli IHSG terhenti setelah empat hari berturut-turut mengalami penguatan. Nilai transaksi mencapai $\mathrm{Rp} \mathrm{6,4} \mathrm{triliun,} \mathrm{turun} \mathrm{drastis} \mathrm{jika} \mathrm{dibandingkan} \mathrm{perdagangan} \mathrm{akhir} \mathrm{pekan} \mathrm{lalu} \mathrm{yang}$ mencapai Rp 9 triliun. Aksi ambil untung investor lokal terus berlanjut mengingat investor asing justru masuk, melakukan pembelian saham senilai Rp 600 miliar di semua pasar". Informasi tersebut menunjukkan bahwa perilaku investor berbeda-beda, seperti menjual sahamnya, melakukan wait and see, dan membeli saham.

Penelitian yang membahas tentang kandungan suatu informasi pada suatu peristiwa sudah banyak dilakukan. Temuan hasil penelitian ini sesuai dengan penelitian yang dilakukan 
oleh Lestari dan Nuzula (2018) yang meneliti tentang peristiwa peresmian Britain Exit (Brexit) dengan hasil yang menunjukkan bahwa event Brexit mengandung informasi yang mampu membuat pasar bereaksi, akan tetapi kandungan infromasi tersebut tidak cukup besar untuk membentuk nilai beda yang signifikan antara sebelum dan sesudah peristiwa. Hasil penelitian Lestari dan Nuzula (2018) sejalan dengan hasil penelitian ini, adanya persamaan hasil ini disebabkan karena peristiwa yang diteliti memiliki persamaan adanya kandungan informasi namun tidak dapat membentuk nilai beda yang signifikan.

\section{SIMPULAN}

Hasil penelitian ini menunjukkan bahwa Bursa Efek Indonesia merupakan pasar modal yang sedang berkembang dan termasuk dalam thin market atau pasar modal yang tergolong kecil dalam volume perdagangannya, maka pengujian reaksi pasar menggunakan trading volume activity lebih unggul daripada menggunakan return dalam melihat reaksi investor terhadap suatu peristiwa. Selain itu, pengujian cumulative abnormal return dengan rentang waktu yang lebih lama sepanjang jendela atau hasil jual beli investor selama satu minggu dapat memperlihatkan perbedaan yang signifikan sebelum dan sesudah peristiwa. Namun demikian, terdapat potensi bias informasi dari peristiwa yang diteliti.

Titik ekuilibirum dari hasil pengujian trading volume activity terdapat pada $\mathrm{t}_{+3}$ yaitu menghasilkan bahwa tidak terdapat perbedaan yang signifikan sebelum dan sesudah peristiwa. Hal tersebut dapat dikatakan bahwa reaksi pasar terhadap suatu peristiwa terjadi selama 2 hari atau $t_{+1}$ dan $t_{+2}$, pada hari selanjutnya atau selebihnya pasar akan kembali bergerak secara normal.

\section{PUSTAKA ACUAN}

Bungin, B. 2011. Metodologi Penelitian Kuantatif. Edisi 2. Jakarta: Prenada Media Group.

Elad, F.H. 2017. Event Study on the Reaction of Stock Returns to Acquisition News. International Finance and Banking, Vol. 4, No. 1. doi: http://dx.doi.org/10.5296/ifb.v4i1.10409.

Fahmi, I. 2012. Pengantar Pasar Modal. Bandung: Alfabeta.

Fauzi, dkk. Islamic Bond Announcement: Is There Any Effect on Returns? Global Business Review, 18(2) 327-347. doi: http://dx.doi.org/10.1177/0972150916668602.

Ghozali, I. 2011. Aplikasi Analisis Multivariative Dengan Program IBM SPSS 19. Edisi 5. Semarang: Universitas Diponegoro.

Hartono, J. 2012. Pasar Efisien Secara Informasi, Operasional, dan Keputusan. Edisi 2. Yogyakarta: BPFE.

Heze, E. 2018. Perubahan Bobot Indeks Saham: Free Float Adjusted Index. (Online), (http:// www.sahamgain.com/2018/11/perubahan-bobot-indeks-saham-free-float.html?m=1), diakses 15 November 2018.

Kholidah, A.M. 2017. Perbedaan Abnormal Return Sebelum Dan Sesudah Maraknya Isu Kenaikan Harga Rokok. Skripsi tidak diterbitkan. Malang: FE UM.

Lathifah, R.N. 2016. Reaksi Pasar Modal Indonesia Terhadap Pengumuman Kebijakan Pengampunan Pajak. Yogyakarta: FEB UGM. 
Lestari \& Nuzula. Dampak Britain Exit Terhadap Abnormal Return dan Trading Volume Activity Pada Indeks LQ45. Jurnal Administrasi Bisnis, Vol. 55 No. 3.

Liu, Y. 2008. ISO9000 Certification Effect: Evidence from China. Asian Journal on Quality, Vol. 9 Iss 3 pp.15 - 27. doi: http://dx.doi.org/10.1108/15982688200800025.

Mayrani, W. 2018. Reaksi Pasar Modal Terhadap Peristiwa Demonstrasi 4 November 2016. Skripsi tidak diterbitkan. Malang: FE UM.

Mui, dkk. 2016. The effect of white collar crime announcement on stock price performance: evidence from Malaysian stock market. Journal of Financial Crime, Vol. 23 Iss 4 pp. doi: http://dx.doi.org/10.1108/JFC-03-2015-0016.

Muttaqin, A.A. 2017. Pengaruh Pengumuman Laba (Good News dan Bad News) Terhadap Reaksi Harga Saham Di Bursa Efek Indonesia: Studi Terhadap Saham-Saham Di Indeks LQ45. Yogyakarta: FEB UGM.

Nazir, M. 2005. Metode Penelitian. Jakarta: Ghalia Indonesia.

Saragih, H.P. 2018. Sempat Terbang Saham HM Sampoerna Anjlok 10\%. (Online), (https:// www.cnbcindonesia.com/market/20181109152533-17-41423/sempat-terbang-sahamhm-sampoerna-anjlok-10-ini-sebabnya), diakses 15 November 2018.

Penerapan Free Float Pada Perhitungan Indeks LQ45 dan IDX30. Bank Indonesia. (Online), (http://www.bi.go.id), diakses 15 November 2018.

Rahmadhani, A.H. \& Darmawan, A. 2018. Analisis Abnormal Return Sebelum dan Sesudah Pengumuman Investment Grade Indonesia. Jurnal Administrasi Bisnis, Vol. 59 No. 1.

Repousis, S. 2016. Abnormal stock returns in Greece during the Cypriot banking crisis. Journal of Money Laundering Control, Vol. 19 Iss 2 pp. 122 - 129. doi: http://dx.doi. org/10.1108/JMLC-04-2015-0015.

Rofiuddin, M. 2018. Analisis Perbandingan Harga Saham dan Trading Volume Activity Sebelum dan Sesudah Pengesahan Kebijakan Tax Amnesty. Skripsi tidak diterbitkan. Malang: FE UM.

Rosalina, A. 2018. Analisis Perbedaan Abnormal Return dan Trading Volume Activity Sebelum dan Sesudah di Suspend BEI. Skripsi tidak diterbitkan. Malang: FE UM.

Samsul, M. 2015. Pasar Modal \& Manajemen Portofolio. Jilid 2 Edisi 2. Jakarta: Erlangga.

Santoso, S. 2010. Mastering SPSS 18. Jakarta: Elex Media Komputindo.

Septiani, A.D \& Akbar, L.F. 2014. Pengaruh Merger dan Akuisisi Terhadap Return Perusahaan Yang Bertindak Sebagai Bidder. Jakarta: FE UI.

Setiyaningsih, E. 2018. Dampak Penerapan Aturan Free Float Oleh BEI. (Online), (https:// www.alinea.id/bisnis/dampak-penerapan-aturan-free-float-oleh-bei-b1U8T9flx), diakses 15 November 2018.

Sugiyono. 2016. Metode Penelitian Kuantatif, Kualitatif, dan R\&D. Bandung: Alfabeta.

Susanto, D. \& Sabardi, A. 2002. Analisis Teknikal di Bursa Efek Indonesia. Yogyakarta: STIE YKPN.

Tandelilin, E. 2010. Portofolio dan Investasi Teori dan Aplikasi. Edisi Pertama. Yogyakarta: Kanisius.

Universitas Negeri Malang. 2017. Pedoman Penulisan Karya Ilmiah: Skripsi, Tesis, Disertasi, Artikel, Makalah, Tugas Akhir, Laporan Penelitian. Edisi Keenam. Malang: Universitas Negeri Malang. Uswa, dkk. 2016. The Reaction Of Capital Market Towards Government Decision Regarding Execution Of Drugs. RJOAS, 12(60). doi: https://doi.org/10.18551/rjoas.2016-12.27. 